\title{
THE USE OF MODIFIED GLOBIN AS A PROTEIN SUPPLEMENT IN NORMAL INDIVIDUALS ${ }^{1}$
}

\author{
BY CHRISTINE WATERHOUSE, E. HENRY KEUTMANN, AND \\ LEONARD D. FENNINGER \\ (From the Department of Medicine, School of Medicine and Dentistry, University of \\ Rochester, Rochester, N. Y.)
}

(Submitted for publication February 25, 1953; accepted June 3, 1953)

In recent years there has been great interest in the use of substances which can be given intravenously to expand the volume of the blood. Perhaps for even a longer time there has been a search for protein substances which can be administered parenterally as food supplements. Plasma (1) and human serum albumin $(2,3,4)$ have been used with partial success for both purposes. The latter, particularly, has been shown to be well utilized and easy to administer, but large quantities have proven to be time-consuming and expensive to prepare. With the present blood processing program there is inevitable wastage of human red blood cells and many people have felt that perhaps the protein moiety of such cells might be utilized for either of the above needs. Evidence exists that protein equilibrium can be maintained in animals with hemoglobin as the main source of protein (5).

Modified Globin ${ }^{2}$ has been prepared from human red blood cells by partial hydrolysis. The globin has been characterized as having a uniform molecular weight of about 34,000 . The final $\mathrm{pH}$ of the solution has been adjusted to 7.4. We have given this substance intravenously to patients as a supplement to a low protein diet. Metabolic studies were carried out in a manner similar to that used previously with human serum albumin (2). It was hoped that exactly comparable results could be obtained by the daily intravenous administration of the same amount (60 grams) of the test protein. Since the desired caloric intake could not be maintained in any patient when globin was given at such levels, this was not entirely realized. Nevertheless, cer-

1 This investigation was supported in part by a research grant from the National Heart Institute of the National Institutes of Health, Public Health Service.

2 The globin used in these studies was prepared and generously supplied by Sharp \& Dohme, Inc. tain fundamental differences between the metabolism of globin and albumin were apparent.

\section{PATIENTS AND PROCEDURES}

The clinical background of the four patients concerned in this study was as follows:

H. B., male, age 35, was admitted to the hospital for hysterical symptoms. He had lost about 20 lbs. in the year prior to this study. There was no evidence of organic disease.

G. V., male, age 25 , had rheumatic heart disease with mitral stenosis and insufficiency, and aortic stenosis and insufficiency. This patient had been a subject on the metabolism ward twice before and had on one occasion received intravenous serum albumin. It was felt that comparative effects of albumin and globin in this patient would be of considerable interest.

E. C. was a 51 year old white male with probable peripheral neuritis. His admission to the hospital was precipitated by difficulty in walking. Although it is probable that alcoholism was responsible for his neurological difficulty, no evidence of liver disease was found.

P. B., female, age 26 , had a severe psychoneurosis. The patient was poorly nourished, but had no organic disease.

Each patient was given a two-day rotating basic diet supplemented by calcium gluconate and $\mathrm{KH}_{2} \mathrm{PO}_{4}$. The menus for the two days varied but slightly and their composition was as close to identical as possible. According to repeated analyses of these diets the average daily intakes were as follows:

$\begin{array}{lcrrrrrc} & \mathrm{N} & \mathrm{P} & \mathrm{Ca} & \underset{\mathrm{Na}}{\mathrm{N}} & \underset{m E q .}{\mathrm{Cl}} & \underset{m E q .}{\mathrm{K}} & \text { Cal. } \\ \text { H. B } & 4.03 & 1.04 & .85 & 60 & 70 & 102 & 2502 \\ \text { G. V. } & 3.43 & .99 & .86 & 6 & 6 & 85 & 2230 \\ \text { E. C. } & 4.23 & 1.02 & .91 & 63 & 70 & 103 & 2470 \\ \text { P. B. } & 3.77 & .99 & .84 & 47 & 51 & 78 & 2222\end{array}$

Analysis of the globin:

\begin{tabular}{lccccc} 
& $\mathrm{N}$ & $\mathrm{P}$ & $\mathrm{Na}$ & $\mathrm{Cl}$ & $\mathrm{K}$ \\
$\begin{array}{l}\text { Lot No. 89049-4 } \\
\text { (1 unit) }\end{array}$ & 2.38 & .006 & 21.5 & 16 & .015 \\
$\begin{array}{c}\text { Lot No. 91213 } \\
\text { (1 unit) }\end{array}$ & 2.41 & .004 & 16.9 & 8.5 & .01 \\
\hline $\begin{array}{ll}m E q . \\
\text { (1) }\end{array}$ & & & & &
\end{tabular}

Additional sodium chloride was given in the control periods in amounts comparable to that which was contained in the globin solution. This was withdrawn during the time of intravenous globin administration. 
With the exception of the last case, each patient was carried through an initial 12 day control study. In H. B. and G. V., during the first two experiments done, four units of globin were given each day in divided doses (each unit was dissolved in $400 \mathrm{cc}$. of $3 \frac{1}{2}$ per cent dextrose), the time of administration in each instance being about $1 \frac{1}{2}$ hours. In later experiments only two units of globin were given each day as supplements.

\section{METHODS}

The methods used were the same as those described previously in the work with human serum albumin given intravenously (2). In addition, globin levels in blood and urine were determined by the method of Kendall and Abell (6).

\section{CLINICAL RESULTS}

H. B.: Two hours following the first intravenous injection of two units of globin, the patient became nauseated. The second injection given four hours later was followed by a chill and temperature rise of $39.5^{\circ} \mathrm{C}$. The patient again complained of nausea. From this time on the patient was given $50 \mathrm{mg}$. of pyribenzamine and two APC tablets one-half hour before each injection. He was asymptomatic on the second and third days. On the fourth day he again complained of nausea and vomited three times. The globin was, however, continued for a total of eight days. The vomiting became persistent on the seventh and eighth days, and the patient refused most of his diet at this time. After globin was stopped the patient continued to have nausea and emesis for four additional days. Following this, he was again able to tolerate his diet for a post injection control study of eight days.

G. V.: Shortly after the second injection on the first day of globin administration, the patient had a chill, felt "full," but continued to eat his diet. On the third day, after the morning injection, the patient complained of severe nausea, and refused to eat. The globin was stopped at this time, but nausea and vomiting occurred during the next two days.

After these two experiences it was decided to give only two units daily in the succeeding experiments. Another control period was, therefore, carried out on G. V. and then a series of injections of two units daily was given. (This has been called Experiment No. 2 on G. V. throughout the paper.) At this level the pa- tient was able to tolerate globin for a ten-day period without undue symptoms. He did complain of nausea and headaches occasionally, but ate all his diet during this time and during the twelve-day control period after globin.

E. C.: This patient had no febrile response at any time. Following seven days of intravenous globin, two units each day, the patient stated that he was unable to eat his diet and the experiment had to be discontinued.

P. B.: This patient received two units of globin daily for seven days without incident. On the eighth day she complained of persistent nausea and refused to eat. She vomited frequently for the next two days and even after the globin was discontinued. Four days elapsed before the patient was able to eat her full diet.

\section{LABORATORY RESULTS}

\section{Body weight}

A small initial weight loss occurred in each patient which was regained as globin was continued. No striking effect on body weight was seen in any patient (see Table I).

\section{Hematocrit}

In the two patients who developed azotemia (H. B. and P. B.) a slight drop in hematocrit developed while the nitrogen retention was occurring. There were no changes in hematocrit which could be attributed to globin administration itself. This lack of change is in distinct contrast to that seen when albumin was administered, where repeated injections caused a progressive fall in the per cent of red cells.

\section{Serum protein}

There was no consistent change noted in any of the serum protein components with the exception of a slight increase of $\alpha_{1}$ globulin found in all patients. In three patients there was no significant change in the albumin concentration, while in the fourth, H. B., the value fell $.9 \mathrm{mg}$. per cent. This reduction in serum albumin concentration occurred during a period of azotemia which is discussed below.

\section{Blood levels of globin}

Only a few determinations of plasma globin levels were carried out. All samples were taken 
TABLE I

Nitrogen balances

\begin{tabular}{|c|c|c|c|c|c|c|c|c|c|}
\hline \multirow[b]{2}{*}{ Patient } & \multirow[b]{2}{*}{ Period } & \multirow[b]{2}{*}{ Days } & \multirow[b]{2}{*}{ Body wt. } & \multicolumn{5}{|c|}{ Nitrogen } & \multirow[b]{2}{*}{$\begin{array}{c}\text { Globin } \\
\text { administerec }\end{array}$} \\
\hline & & & & Intake & Urine & Stool & $\begin{array}{l}\text { Emesis and } \\
\text { refused } \\
\text { food }\end{array}$ & Balance & \\
\hline & & & & $\underset{\substack{\text { Gm. per } \\
\text { period }}}{ }$ & $\underset{\substack{\text { Geriod } \\
\text { period }}}{ }$ & $\underset{\substack{\text { Gm.period } \\
\text { periog }}}{ }$ & $\underset{\substack{\text { Geriod } \\
\text { Ger }}}{c}$ & 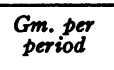 & Units per day \\
\hline H. B. & $\begin{array}{l}\text { I } \\
\text { II } \\
\text { III } \\
\text { IV } \\
\text { V } \\
\text { VI }\end{array}$ & $\begin{array}{l}6 \\
6 \\
6 \\
3 \\
6 \\
6\end{array}$ & $\begin{array}{l}\mathbf{5 2 . 2 5} \\
\mathbf{5 2 . 3 4} \\
\mathbf{5 1 . 8 8} \\
\mathbf{5 2 . 9 0} \\
\mathbf{5 3 . 2 5} \\
\mathbf{5 0 . 8 1} \\
\mathbf{5 0 . 3 4}\end{array}$ & $\begin{array}{l}24.2 \\
24.2 \\
80.9 \\
31.1 \\
24.2 \\
24.4\end{array}$ & $\begin{array}{l}22.5 \\
20.0 \\
49.3 \\
11.0 \\
49.4 \\
38.1\end{array}$ & $\begin{array}{l}7.6 \\
7.6 \\
7.6 \\
2.8 \\
5.6 \\
5.6\end{array}$ & $\begin{array}{l}\bar{Z} \\
1.1 \\
3.6 \\
3.6 \\
-\end{array}$ & $\begin{array}{r}-5.9 \\
-\quad 3.4 \\
+22.9 \\
+13.7 \\
-34.4 \\
-19.5\end{array}$ & $\begin{array}{l}4 \\
4\end{array}$ \\
\hline G. V. & $\begin{array}{l}\text { I } \\
\text { II } \\
\text { III } \\
\text { IV } \\
\text { V } \\
\text { VI } \\
\text { VII } \\
\text { VIII }\end{array}$ & $\begin{array}{l}6 \\
6 \\
3 \\
3 \\
3 \\
4 \\
6 \\
4 \\
6 \\
4 \\
4\end{array}$ & $\begin{array}{l}\mathbf{5 8 . 1 5} \\
\mathbf{5 7 . 6 1} \\
\mathbf{5 7 . 8 7} \\
\mathbf{5 6 . 7 8} \\
\mathbf{5 6 . 0 8} \\
\mathbf{5 7 . 7 9} \\
\mathbf{5 6 . 4 1} \\
\mathbf{5 7 . 0 4} \\
\mathbf{5 6 . 1 0} \\
\mathbf{5 6 . 2 1}\end{array}$ & $\begin{array}{r}20.6 \\
20.6 \\
34.3 \\
-\quad 10.3 \\
13.7 \\
49.4 \\
32.9 \\
20.6 \\
13.7\end{array}$ & $\begin{array}{l}30.0 \\
19.4 \\
27.8 \\
16.6 \\
16.4 \\
38.3 \\
26.1 \\
25.3 \\
15.7\end{array}$ & $\begin{array}{l}6.8 \\
6.8 \\
3.1 \\
3.1 \\
4.2 \\
5.8 \\
3.8 \\
5.8 \\
4.3\end{array}$ & $\begin{array}{l}\bar{z} \\
\overline{3.3} \\
= \\
= \\
=\end{array}$ & $\begin{array}{r}-16.2 \\
-5.6 \\
+\quad 3.4 \\
-12.7 \\
-6.9 \\
+5.3 \\
+3.0 \\
+7.5 \\
-6.3\end{array}$ & 2 \\
\hline E. C. & $\begin{array}{l}\text { II } \\
\text { III }\end{array}$ & $\begin{array}{l}6 \\
6 \\
6\end{array}$ & $\begin{array}{l}\mathbf{5 8 . 7 2} \\
\mathbf{5 8 . 7 8} \\
\mathbf{5 8 . 9 5} \\
\mathbf{5 7 . 4 7}\end{array}$ & $\begin{array}{l}25.4 \\
25.4 \\
54.3\end{array}$ & $\begin{array}{l}22.5 \\
21.4 \\
41.1\end{array}$ & $\begin{array}{r}10.6 \\
9.5 \\
8.2\end{array}$ & $\bar{z}$ & $\begin{array}{l}-7.7 \\
=5.5 \\
+5.0\end{array}$ & 2 \\
\hline P. B. & $\begin{array}{l}\text { I } \\
\text { II } \\
\text { III } \\
\text { IV }\end{array}$ & $\begin{array}{l}6 \\
6 \\
4 \\
6\end{array}$ & $\begin{array}{l}54.4 \\
54.33 \\
53.80 \\
54.52 \\
51.79\end{array}$ & $\begin{array}{l}22.6 \\
51.6 \\
34.4 \\
22.6\end{array}$ & $\begin{array}{l}15.1 \\
33.9 \\
13.1 \\
29.2\end{array}$ & $\begin{array}{l}7.4 \\
6.9 \\
2.8 \\
4.1\end{array}$ & $\begin{array}{r}\overline{1.9} \\
7.4 \\
11.2\end{array}$ & $\begin{array}{r}+0.1 \\
+8.9 \\
+11.1 \\
-21.9\end{array}$ & $\begin{array}{l}2 \\
2\end{array}$ \\
\hline
\end{tabular}

at least 12 hours after any injection had been given. The values obtained were as follows:

1) H. B. $-93 \mathrm{mg}$. per cent-after eight days of globin administration

2) G. V.- - too low to measure after ten days of globin administration

3) P. B. $-130 \mathrm{mg}$. per cent-after ten days of globin administration

4) E. C. $-130 \mathrm{mg}$. per cent-after eight days of globin administration

These results suggest that even after repeated daily injections, there is little accumulation of globin in the serum.

\section{Blood urea nitrogen}

In two patients there was a progressive rise of blood urea nitrogen during the administration of globin, as seen in Table II. In H. B. it rose from $7 \mathrm{mg}$. per cent to $62 \mathrm{mg}$. per cent. During the twelve days of post injection study the level fell to $18 \mathrm{mg}$. per cent. Unfortunately, no kidney function studies were done on the patient prior to the injections; however, fifteen days after they were stopped para-amino-hippurate clearances were 463 and $408 \mathrm{ml}$. of plasma per minute and urea clearances during two consecutive hours were 39 per cent and 40 per cent of the normal average. One month later the urea clearances were 73 per cent and 75 per cent of normal. In P. B., the blood urea nitrogen rose from $4 \mathrm{mg}$. per cent to $31 \mathrm{mg}$. per cent. In this subject the urea clearance capacity was the same three weeks after globin had been discontinued as it had been prior to globin ( 72 per cent and 87 per cent before, and 74 per cent and 78 per cent after).

The rise of blood urea nitrogen as a point of evidence for lowered glomerular filtration is of some clinical importance, even though renal function apparently returned to normal in both instances. The possibility of dehydration from vomiting as a contributing cause has been considered but not thought responsible.

A careful accounting of the water exchange 
showed that the intake, augmented by the intravenous fluids, was at all times greater than the output by a liberal margin, and the patients gained weight while azotemia and oliguria were developing.

\section{Nitrogen balances}

These are recorded in Table $I$ and Figures 1 to 4. During the control periods on the basic low protein diets, three patients were in slightly negative nitrogen balance and one remained in balance.

In contrast to studies previously done with albumin (2) on the first day of globin administration the urinary nitrogen rose promptly (Figures

TABLE II

The levels of blood urea nitrogen before and during administration of globin*

\begin{tabular}{lcccc}
\hline \hline Period & H. B. & G. V. & E. C. & P. B. \\
\hline & mg. \% & mg. \% & mg. \% & mg. \% \\
0 & 10 & 14 & 8 & 8 \\
I & & 7 & & 4 \\
II & 7 & 5 & 4 & 5 \\
III & 26 & 4 & 6 & 31 \\
IV & 62 & 6 & & $21-11$ \\
V & $63-59-41$ & 8 & & \\
VI & 18 & 10 & & \\
VII & & 6 & & 12 \\
\hline
\end{tabular}

* The blocked-in numbers denote the periods during which globin was administered. Where single values are in the table they were obtained at the end of the designated periods. For length of periods see Table I. There was an interval of 14 days between the last two determinations on P. B.

1-4). Each subject remained in positive nitrogen balance during the time of intravenous injections, but the amount retained was far less than was observed with comparable amounts of albumin. In one instance (P. B.), where dietary intake fell below caloric requirements, a negative nitrogen balance was seen during the last two days of globin administration (see period 3 in Figure 4).

The post injection control periods were of little value in $H$. B. and $P . B$., and in the first experiment on G. V., because of the inability of the patients to tolerate their diets. In the second experiment on G. V. conditions were satisfactory and one notes a nitrogen balance similar in all respects to that seen in the initial control periods (periods 7 and 8 in Figure 2).

\section{H.B. MALE AGE $35 \# 322806$}

\begin{tabular}{|c|c|c|c|c|}
\hline \multirow{3}{*}{$\begin{array}{l}\text { GLOBIN } \\
\text { GLOBIN }\end{array}$} & \multirow[b]{2}{*}{ ADM } & \multicolumn{3}{|c|}{ GRAMS NITROGEN } \\
\hline & & 50.6 & 17.4 & 0 \\
\hline & IN URINE & 13.7 & 3.0 & 1.5 \\
\hline OBIN & DEAMINATED & 17.4 & 12.5 & $? 7.3$ \\
\hline & & 20.0 & 一 & \\
\hline
\end{tabular}

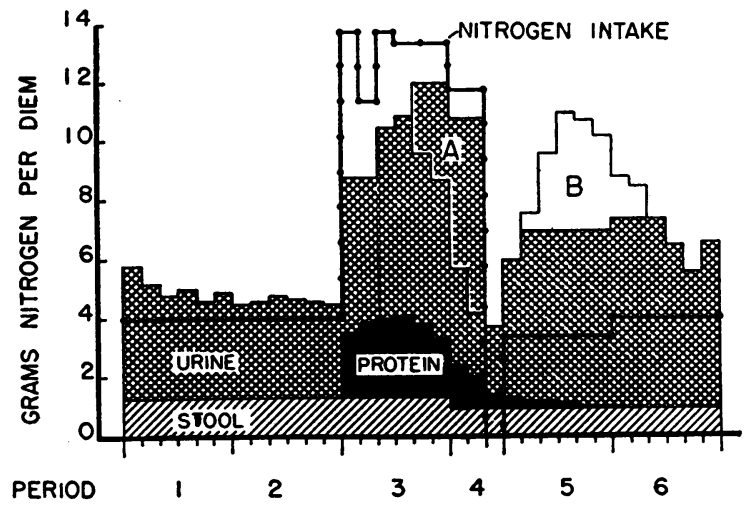

Fig. 1. Nitrogen Balance on H. B. Before, During, and After Intravenous Administration of Modified Globin as a Supplement to a Low Protein Diet

Area $A$ represents protein deaminated and then temporarily retained. This was excreted as shown in area B. The cross-hatched area, therefore, shows the corrected urinary non-protein nitrogen and thus helps visualize the "true" metabolism of protein period by period.

\section{Protein in urine}

Quantitative values for urinary protein were determined in three ways:

\section{G.V. MALE AGE 25 \# 182390}
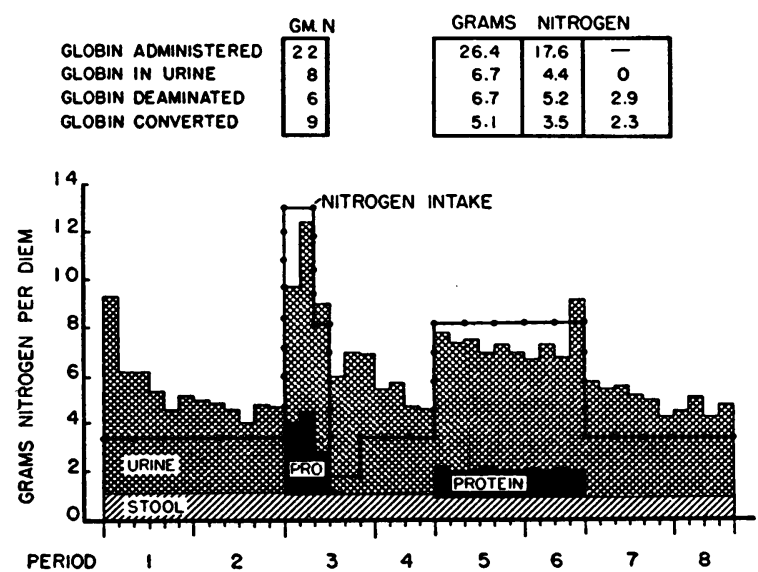

Fig. 2. Nitrogen Balance on G. V. Before, DurING, AND AFter Intravenous Administration OF Modified Globin as a Supplement to a Low Protein Diet 


\section{E.C. MALE AGE 41 \#334093}

\begin{tabular}{l|r} 
& \multicolumn{1}{c}{ GM. N } \\
\hline GLOBIN ADMINISTERED & 26.4 \\
GLOBIN IN URINE & 6.6 \\
GLOBIN DEAMINATED & 9.3 \\
GLOBIN CONVERTED & 8.6 \\
\hline
\end{tabular}

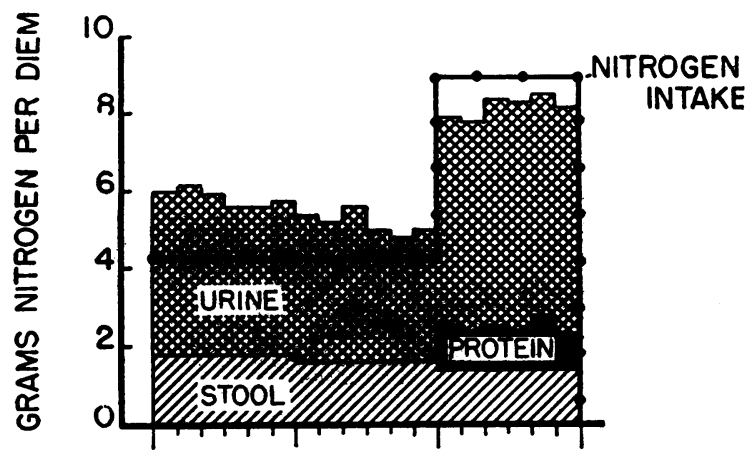

\section{$\begin{array}{llll}\text { PERIOD } & 1 & 2 & 3\end{array}$}

Fig. 3. Nitrogen Balance on E. C. Before and During Intravenous Administration of Modified Globin as a Supplement to a Low Protein Diet

1) The biuret reaction (7).

2) Total nitrogen by the Kjeldahl Method minus the non-protein nitrogen in the urine.

3) Globin per se by the method of Kendall and Abell (6). This method depends on the observation that trichloracetic acid, buffered to a $\mathrm{pH}$ of 4.7 with sodium citrate, precipitates globin selectively.

By all three methods the results were quite similar. Figures derived from the biuret determinations only are given in Table III. Confirmatory evidence that this protein was globin and not albumin was obtained when precipitation with cationic detergents occurred at an isoelectric point quite different from that of albumin.8

It is of interest that the highest percentage of excretion occurred in G. V., who also excreted larger quantities of albumin than other subjects in the previous study (2). With H. B. and $P$. B. the decreasing excretion beginning after the sixth day occurred while the blood urea nitrogen was rising.

Aside from these variations the amount ex-

8 These determinations were carried out through the courtesy of Dr. Eric L. Alling, Department of Radiation Biology, University of Rochester. creted in the urine each day was roughly proportional to the amount given. There was apparently no cumulative effect, the same amount having been excreted during the first day of administration as the last. There was no appreciable excretion of globin after the injections were stopped.

\section{Phosphorus balances}

Three of the four patients were in phosphorus equilibrium at the end of the control periods. As seen in Table II, retention of phosphorus occurred in all patients during the injections of globin. Although the daily values are not recorded in this paper, it should be stated that the drop of urinary phosphorus which occurred with globin was apparent on the first day. As will be discussed below, this may be interpreted to mean that conversion of this protein to body tissue begins promptly.

\section{Urinary calcium excretion}

It is worth noting that the urinary calcium decreased in all instances when globin was given, while for the most part the stool excretion was unaffected. The resultant positive balances, recorded in Table IV, were established. This ef-

\section{P.B. FEMALE AGE 26 \#66014

\begin{tabular}{llr|r|}
\multicolumn{4}{c}{ GRAMS NITROGEN } \\
GLOBIN ADMINISTERED & 28.5 & 19.0 \\
GLOBIN & IN URINE & 6.5 & 2.5 \\
GLOBIN & DEAMINATED & 13.5 & 14.9 \\
GLOBIN & CONVERTED & 4.6 & 1.1 \\
\hline
\end{tabular}

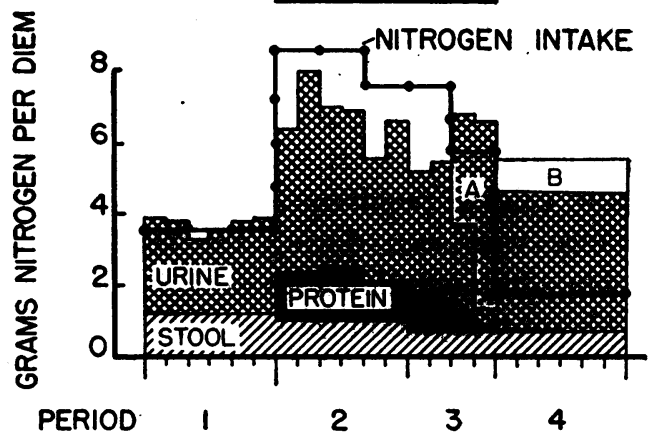

Fig. 4. Nitrogen Balance on P. B. Before, DurING, AND After Intravenous Administration of Modified Globin as a Supplement to a Low Protern Diet

Explanation for areas $A$ and $B$ is the same as for Figure 1. 
TABLE III

Urinary excretion of globin*

\begin{tabular}{|c|c|c|c|c|c|c|c|c|c|c|c|}
\hline \multirow[b]{2}{*}{ Day } & \multirow[b]{2}{*}{. } & \multicolumn{2}{|c|}{ H. B. } & \multicolumn{4}{|c|}{ G. V. } & \multicolumn{2}{|c|}{ E. C. } & \multicolumn{2}{|c|}{ P. B. } \\
\hline & & $\begin{array}{l}\text { Amt. } \\
\text { given }\end{array}$ & $\begin{array}{c}\text { Amt. } \\
\text { excreted }\end{array}$ & $\begin{array}{c}\text { Amt. } \\
\text { given } \\
\text { Exp. No. } 1\end{array}$ & $\begin{array}{c}\text { Amt. } \\
\text { excreted } \\
\text { Exp. No. } 1\end{array}$ & $\begin{array}{c}\text { Amt. } \\
\text { given } \\
\text { Exp. No. } 2\end{array}$ & $\begin{array}{c}\text { Amt. } \\
\text { excreted } \\
\text { Exp. No. } 2\end{array}$ & $\begin{array}{l}\text { Amt. } \\
\text { given }\end{array}$ & $\begin{array}{c}\text { Amt. } \\
\text { excreted }\end{array}$ & I Amt. & $\begin{array}{c}\text { Amt. } \\
\text { excreted }\end{array}$ \\
\hline $\begin{array}{r}1 \\
2 \\
3 \\
4 \\
5 \\
6 \\
7 \\
8 \\
9 \\
10\end{array}$ & . & $\begin{array}{c}\text { Gm. } \\
64 \\
48 \\
64 \\
64 \\
64 \\
64 \\
64 \\
64 \\
0\end{array}$ & $\begin{array}{c}\text { Gm. } \\
13.8 \\
10.3 \\
16.9 \\
17.4 \\
15.6 \\
12.6 \dagger \\
9.1 \\
6.9 \\
2.7\end{array}$ & $\begin{array}{c}\text { Gm. } \\
64 \\
64 \\
32\end{array}$ & $\begin{array}{l}\text { Gm. } \\
18.5 \\
21.8 \\
10.9\end{array}$ & $\begin{array}{c}G m . \\
32 \\
32 \\
32 \\
32 \\
32 \\
32 \\
32 \\
32 \\
32 \\
32\end{array}$ & $\begin{array}{c}G m . \\
7.7 \\
6.9 \\
6.7 \\
7.8 \\
6.9 \\
6.6 \\
7.2 \\
6.7 \\
7.1 \\
6.6\end{array}$ & $\begin{array}{c}\mathbf{G m} . \\
32 \\
32 \\
32 \\
32 \\
32 \\
32\end{array}$ & $\begin{array}{c}G m . \\
7.4 \\
6.2 \\
7.2 \\
6.6 \\
7.9 \\
6.1\end{array}$ & $\begin{array}{c}G m . \\
32 \\
32 \\
32 \\
32 \\
32 \\
32 \\
32 \\
32 \\
32 \\
32\end{array}$ & $\begin{array}{l}G m . \\
6.6 \\
6.7 \\
7.6 \\
7.4 \\
6.9 \\
6.3 \\
5.9 \dagger \\
5.8 \\
3.5 \\
.6\end{array}$ \\
\hline
\end{tabular}

* The amounts of globin recorded here as having been given are according to the labels on the bottles, i.e., 16 grams of globin per unit. The number of units varied from two to four daily. The intake values in all other tables and figures are taken from analyses performed on each lot.

$\dagger$ BUN started to rise.

fect has previously been observed when albumin was given. It was attributed to bone formation with the latter and may represent the same phenomenon in this instance.

\section{Fate of the injected protein}

An accounting of the injected globin was carried out in a manner similar to that used for serum albumin, i.e.,

1) Globin deaminated,

2) Globin converted to tissue protein,

3) Globin remaining unchanged in the body,

4) Globin excreted in the urine.

In calculating the deamination of globin it was assumed that as long as a patient consumed the same basal diet he deaminated protein other than globin at the same rate during the entire experiment. Whenever patients were unable to eat this diet or vomited, the nitrogen balance data were obviously not suitable for the calculations. It was also necessary to make adjustments for the observed changes in blood urea nitrogen (see Table II and Figures 1 and 4). Accordingly, the deaminated globin was considered to be represented by: the increased nitrogen excretion above control levels, minus nitrogen excreted as globin, plus the increase of urea nitrogen in the body. The urea was considered equally distributed throughout 60 per cent of the body weight.

The values as obtained on each patient are presented in Table $V$. They are stated as the amount of globin nitrogen deaminated and the percentage of the globin administered which this represents. It is important to emphasize that the deamination and excretion of globin began in each case during the first day of injection and continued at about the same levels until a critical reduction of caloric intake occurred $(\mathrm{H}$. B., Period IV ; P. B., Period III). As stated above, because of the dietary limitations, the values in the post injection control periods cannot be considered as valid criteria for the deamination of globin alone except in the case of G. V. In the post injection periods of the second experiment on this patient there was no evidence of increased excretion of nitrogen above the control level (Figure 2, periods 7 and 8 ). This indicates that

TABLE IV

Phosphorus, calcium and theoretical nitrogen balances expressed as deviations from the control periods

\begin{tabular}{|c|c|c|c|c|c|}
\hline & Period & Days & $\begin{array}{c}\text { Phos- } \\
\text { phorus } \\
\text { balance }\end{array}$ & $\begin{array}{l}\text { Calcium } \\
\text { balance }\end{array}$ & $\begin{array}{c}\text { Theoreti } \\
\text { cal N } \\
\text { balance }\end{array}$ \\
\hline & & & $\underset{\text { period }}{\text { Gm. per }}$ & $\underset{\text { period }}{\text { Gm. per }}$ & $\underset{\text { period }}{\text { Gm.per }}$ \\
\hline H. B. & $\begin{array}{l}\text { III } \\
\text { IV }\end{array}$ & $\begin{array}{l}6 \\
3\end{array}$ & $\begin{array}{l}+1.54 \\
+\quad .02\end{array}$ & $\begin{array}{l}+.4 \\
-.24\end{array}$ & $\begin{array}{l}+20 \\
+2\end{array}$ \\
\hline $\begin{array}{l}\text { G. V. } \\
\text { No. } 1 \\
\text { No. } 2\end{array}$ & $\begin{array}{l}\text { III } \\
\text { V } \\
\text { VI }\end{array}$ & $\begin{array}{l}3 \\
6 \\
4\end{array}$ & $\begin{array}{l}+.73 \\
+.35 \\
+.30\end{array}$ & $\begin{array}{l}+.30 \\
+.06 \\
+.08\end{array}$ & $\begin{array}{l}+9 . \\
+5 . \\
+4 .\end{array}$ \\
\hline E. C. & III & 6 & +.85 & +.59 & +9 \\
\hline P. B. & $\begin{array}{l}\text { II } \\
\text { III }\end{array}$ & $\begin{array}{l}6 \\
4\end{array}$ & $\begin{array}{r}+.40 \\
+.37\end{array}$ & $\begin{array}{l}+.19 \\
+.72\end{array}$ & $\begin{array}{l}+5 . \\
+1 .\end{array}$ \\
\hline
\end{tabular}


TABLE $\mathbf{V}$

Deamination of globin

\begin{tabular}{|c|c|c|c|c|c|}
\hline Patient & Period & Days & $\begin{array}{l}\text { Globin } \\
\text { given }\end{array}$ & Globin d & aminated \\
\hline H. B. & $\begin{array}{l}\text { III } \\
\text { IV }\end{array}$ & $\begin{array}{l}6 \\
3\end{array}$ & $\begin{array}{c}G m . N \\
50.6 \\
17.4\end{array}$ & $\begin{array}{c}G m . N \\
17.4 \\
12.5\end{array}$ & $\begin{array}{c}\begin{array}{c}\text { Per cent of } \\
\text { amount } \\
\text { given }\end{array} \\
34 \\
72\end{array}$ \\
\hline $\begin{array}{l}\text { G. V. } \\
\text { No. } 1 \\
\text { No. } 2\end{array}$ & $\begin{array}{l}\text { III } \\
\text { V } \\
\text { VI }\end{array}$ & $\begin{array}{l}3 \\
6 \\
4\end{array}$ & $\begin{array}{l}22.0 \\
26.4 \\
17.6\end{array}$ & $\begin{array}{l}6.0 \\
6.7 \\
5.2\end{array}$ & $\begin{array}{l}27 \\
25 \\
30\end{array}$ \\
\hline E. C. & III & 6 & 26.4 & 9.3 & 34 \\
\hline P. B. & $\begin{array}{l}\text { II } \\
\text { III }\end{array}$ & $\begin{array}{l}6 \\
4\end{array}$ & $\begin{array}{l}28.5 \\
19.0\end{array}$ & $\begin{array}{l}13.5 \\
14.9\end{array}$ & $\begin{array}{l}47 \\
78\end{array}$ \\
\hline
\end{tabular}

there was very little metabolism of the globin after the injections were stopped, a situation quite different from that when albumin was given.

The conversion of phosphorus-poor globin to tissue protein has been estimated by the retention of phosphorus associated with injections. The retention of phosphorus has, in each instance, been corrected for the amount which moved with the calcium for bone formation. The amounts of phosphorus and calcium retained have been recorded in Table IV as have the theoretical nitrogen balances (8) derived therefrom. The latter represent the estimated conversion of globin to tissue protein. It will be seen that in all patients this amount was considerable.

The summary data for the burning, excretion, and conversion of globin as percentages of the amounts given are recorded in Table VI. The following points must be emphasized:

1) A high percentage of the globin administered was deaminated and used for fuel only when caloric intake became inadequate (H. B., period IV ; P. B., period III). At other times the conversion of this substance to body protein appeared to occur promptly and efficiently.

2) The amount of globin excreted as such in the urine was about one-quarter of the amount given except when renal insufficiency (as indicated by a rising blood urea nitrogen) became evident ( $H$. B., period IV, P. B. ; period III).

3) In nearly all periods the sum of the amount excreted in the urine, the amount deami- nated, and the amount converted came to approximately 100 per cent. Thus, by exclusion, there was little evidence for storage of unchanged globin in the body at any time during the experiments. This finding correlates well with the low blood levels of globin and the failure of this substance to produce a sustained osmotic effect.

\section{DISCUSSION}

Studies with human serum albumin have indicated a slow degradation of this substance when given intravenously. When large amounts were given a half life of about five and one-half days was obtained (4). In studies in which the albumin was labeled biosynthetically with $\mathrm{N}^{15}$ or $\mathrm{S}^{85}$, values for the half life time of 17 to 20 days were obtained $(9,10)$. The slow metabolism of this native protein is undoubtedly responsible for its prolonged osmotic effect. In contrast, when globin, the natural protein moiety of hemoglobin, was placed in the blood stream it was rapidly metabolized, probably within 24 hours. This fact may diminish the usefulness of this substance as a plasma extender. A transient increase of osmotic pressure may well have occurred with the globin administration, however, since our shortest experimental periods were 24 hours, and blood levels were determined 12 hours after administration.

Our data were derived mainly for the purpose of determining the nutritive value of this protein and, from this point of view, rapid metabolism would seem to be advantageous. Indirect evidence indicates that globin is readily converted to

TABLE VI

Summary of the fate of the globin administered intravenously expressed as per cent of the amount given

\begin{tabular}{lcccccc}
\hline \hline & Period & Days & Burned & $\begin{array}{c}\text { Ex- } \\
\text { creted }\end{array}$ & $\begin{array}{c}\text { Con- } \\
\text { verted }\end{array}$ & Total \\
\hline H. B. & III & 6 & 34 & 27 & 40 & 101 \\
& IV & 3 & 72 & 17 & 11 & 100 \\
G. V. & & & & & & \\
No. 1 & III & 3 & 27 & 36 & 41 & 104 \\
No. 2 & V & 6 & 25 & 25 & 19 & 69 \\
& VI & 4 & 30 & 25 & 20 & 75 \\
E. C. & III & 6 & 34 & 25 & 33 & 92 \\
P. B. & II & 6 & 47 & 23 & 17 & 87 \\
& III & 4 & 78 & 13 & 6 & 97 \\
\hline
\end{tabular}


tissue protein, but as always, one must have an adequate caloric intake to accomplish this. The invariable production of the symptoms of nausea and vomiting, therefore, becomes an important factor in the use of globin as a nutritive supplement. The gastrointestinal difficulty was apparent in each patient after about 12 units had been injected. The cause remains undetermined. Amino acid injections are prone to cause symptoms of nausea and vomiting, although some difference of opinion still exists as to the determinant factor in this reaction (1). The globin was analyzed for non-protein nitrogen on several occasions and less than one-tenth of the material was not in the form of protein. It seems unlikely therefore, that amino acids were responsible for the reactions. As pure speculation, from the pattern of the symptomatology, one might suggest that some product of the hydrolysis, probably not an amino acid, accumulates during repeated injections and eventually produces the symptoms of gastro-intestinal distress.

\section{SUM MARY}

The evidence we have accumulated indicates that:

1) In normal individuals about 25 per cent of injected globin was excreted promptly as such in the urine.

2) There was insignificant accumulation of globin either in the plasma or the extracellular fluid. Metabolism occurred promptly.

3) Amounts comparable to albumin were converted to tissue protein, if the caloric intake was adequate.

Since the preparation of this manuscript a paper has been published of studies on the metabolism of globin, as determined by radioactive labeling. Evidence for rapid metabolism of globin was also found by this method. (Berson,
S. A., Yalow, R. S., Post, J., Wisham, L. H., Newerly, K. N., Villazan, M. J., and Vazquez, O. N., Distribution and fate of intravenously administered modified human globin and its effect on blood volume. Studies utilizing $\mathrm{I}^{131}$ tagged globin. J. Clin. Invest., 1953, 32, 22.)

\section{REFERENCES}

1. Elman, R., Parenteral Alimentation in Surgery, with Special Reference to Proteins and Amino Acids, New York, P. B. Hoeber, Inc., 1947.

2. Waterhouse, C., Bassett, S. H., and Holler, J. W., Metabolic studies on protein-depleted patients receiving a large part of their nitrogen intake from human serum albumin administered intravenously. J. Clin. Invest., 1949, 28, 245.

3. Albright, F., Forbes, A. P., and Reifenstein, E. C., Jr., The fate of plasma protein administered intravenously. Tr. A. Am. Physicians, 1946, 59, 221

4. Eckhardt, R. D., Lewis, L. H., Murphy, T. L., Batchelor, W. H., and Davidson, C. S., Chemical, clinical and immunological studies on the products of human plasma fractionation. XXXIV. Comparative studies on the nutritive value of orally and intravenously administered human serum albumin in man. J. Clin. Invest., 1948, 27, 119.

5. Whipple, G. H., Hemoglobin and plasma proteins: their production, utilization and interrelation. Am. J. M. Sc., 1942, n.s., 203, 477.

6. Kendall, F. E., and Abell, L. L., Personal communication.

7. Kingsley, G. R., The direct biuret method of the determination of serum proteins as applied to photoelectric and visual colorimetry. J. Lab. \& Clin. Med., 1942, 27, 840.

8. Reifenstein, E. C., Jr., Albright, F., and Wells, S. L., The accumulation, interpretation, and presentation of data pertaining to metabolic balances, notably those of calcium, phosphorus and nitrogen. J. Clin. Endocrinol., 1945, 5, 367.

9. London, I. M., Studies on the rates of formation of serum proteins in man, Symposia on Nutrition, Vol. II, The Robert Gould Research Foundation, Inc., Charles C Thomas, publ., 1950, p. 72.

10. Volwiler, W., Fremont-Smith, K., and MacMartin, M. P., Turnover rates of serum proteins in cirrhotic man. J. Clin. Invest., 1952, 31, 668. 